\title{
Effect of grafting and harvest stage on the quality of black cherry tomatoes (Solanum lycopersicum cv. OG) cultivated in Vietnam
}

\author{
${ }_{1,2,3 *}$ Ha, H.T.N. and ${ }^{3}$ Thuy, N.M. \\ ${ }^{1}$ Faculty of Agriculture and Natural Resources, An Giang University, Vietnam \\ ${ }^{2}$ Vietnam National University Ho Chi Minh City, Vietnam \\ ${ }^{3}$ Department of Food Technology, College of Agriculture, Can Tho University, Vietnam
}

\begin{abstract}
Article history:
Received: 18 June 2020

Received in revised form: 26

August 2020

Accepted: 27 September 2020

Available Online: 6

December 2020
\end{abstract}

Keywords:

Bioactive compound,

Black cherry tomato,

Grafting,

Harvest stage,

Solanum lycopersicum cv.

OG

DOI:

https://doi.org/10.26656/fr.2017.5(1).283

\begin{abstract}
Black cherry tomato is an important source of nutraceutical compounds; however, the quality of fruits depends on the cultivation technique and maturity stage at harvest. In this study, the physical and chemical properties of non-grafted and grafted tomatoes (Solanum lycopersicum cv. OG) were evaluated at different stages of maturity to observe the effect of grafting on quality of fruits and select the appropriate harvest stage to achieve the highest content of bioactive compounds, especially anthocyanin. The obtained results found that harvesting non-grafted tomatoes on the $30^{\text {th }}$ day after fruit formation would be suitable for storage with the highest anthocyanin level of $4.27 \mathrm{mg} \mathrm{CE} / 100 \mathrm{~g}$ and the content of other bioactive compounds (lycopene $24.60 \mu \mathrm{g} / \mathrm{g}$, vitamin C $42.79 \mathrm{mg} / 100 \mathrm{~g}$ and total phenolic $40.61 \mathrm{mg} \mathrm{GAE} / 100 \mathrm{~g}$ ). Meanwhile, the optimal harvest stage of grafted tomatoes was shortened, on the $28^{\text {th }}$ day (anthocyanin $4.31 \mathrm{mg} \mathrm{CE} / 100 \mathrm{~g}$, lycopene 38.79 $\mu \mathrm{g} / \mathrm{g}$, vitamin C $55.69 \mathrm{mg} / 100 \mathrm{~g}$, and total phenolic $38.69 \mathrm{mg} \mathrm{GAE} / 100 \mathrm{~g}$ ). The grafting technique should be applied for supporting the plant to grow faster as shown by the earlier stage of harvest and the harvested fruit possessed higher content of bioactive compounds.
\end{abstract}

\section{Introduction}

"Black" or "purple" cherry tomatoes are subspecies of Solanum Lycopersicum (Zhang et al., 2018) and exhibit a purplish-brown color on their skin (Mes et al., 2008). Lycopene is the most abundant (about $80-90 \%$ of total carotenoid content) and the highest antioxidant natural carotenoid found in tomatoes (Alda et al., 2009). Epidemiological studies have shown that lycopene, a red pigment has the potential to reduce the risk of chronic diseases, most notably prostate cancer (Ford and Erdman, 2012). This red pigment also plays an important role in the prevention of cardiovascular disease (Mordente et al., 2011). Min and Min (2014) observed that consuming a large amount of lycopene-rich foods helped to lower the risk of mortality from Alzheimer's disease in adults. Kaur et al. (2011) also found that lycopene was beneficial in the treatment of Parkinson's disease and other neurological abnormalities by protecting against oxidative stress. In addition to carotenoids, tomatoes are good for other antioxidant compounds such as vitamin $\mathrm{C}$ and phenolics which also inhibit reactive oxygen species causing many dangerous diseases (Ilahy et al., 2009). It has been noticed that the content of phenolic compounds and carotenoid pigments, particularly lycopene in black cherry tomatoes are higher than in some red tomato varieties (Zhang et al., 2018). Especially, black cherry tomatoes also can produce a phytochemical of anthocyanin predominantly in the skin (Li et al., 2011). Anthocyanin has been proven to be associated with many health benefits, reduces cancer cell proliferation, protects against cardiovascular disease, prevents obesity and diabetes (Lila, 2004).

Despite containing many bioactive compounds, researches on black cherry tomatoes have been very limited, especially in Vietnam. Moreover, consumers are still sceptical about the anthocyanin component in black cherry tomatoes, because some studies in the world showed that some heirloom varieties result from mutations affecting chlorophyll breakdown and carotenoid content but are not related to anthocyanin production (Gonzali et al., 2009). Therefore, most of the black cherry tomatoes have primarily grown in Vietnamese gardens for visiting and retailing. This wastes a healthy source of black cherry tomatoes and does not create many choices for consumers and also affect the economic benefits for farmers.

Besides that, bacterial wilt, caused by Ralstonia 
solanacearum, can be very problematic for all tomato growers as a result of a lack of available resistance genes within cultivated tomato (Rivard and Louws, 2008). The cultivation of grafted vegetable plants has become more popular recently to manage soilborne pathogens (Besri, 2001; Bletsos, 2005). This technique is carried out when the rootstock and scion seedlings are very small, and the two are attached with a small silicon tube or clip (Rivard and Louws, 2006). Grafting with tolerant rootstock is also effective at overcoming abiotic stresses such as salinity (Cuartero et al., 2006), thermal stress (Rivard and Louws, 2008), and excessive soil moisture (Black et al., 2003). Although the use of grafted vegetables is associated with disease reduction and/or abiotic stressors, yield can be increased without the presence of these identified stressors (Yetisir and Sari, 2003). Grafted plants also produced higher fresh and dry matter than control (Yetisir and Sari, 2003).

The physical and chemical properties of tomatoes not only depend greatly on the grafting but also on the maturity stage at harvest. Maturation caused a slight softening in tomato when compared with less mature tomato fruits, which has a significant effect on the quality and influences consumer preferences, storability, shelf life, pathogen resistance, and transportability (Viskelis et al., 2008). Helyes et al. (2006) found that the Brix, carbohydrate, and lycopene content increased during maturation from the green mature to the deep red stage but polyphenol content changed little during tomato ripening. Moneruzzaman et al. (2008) reported that half-ripen tomato showed the highest value of vitamin $\mathrm{C}$ and titrable acidity.

Therefore, the objective of this study was to evaluate the effect of grafting and harvest stage on the physicochemical properties of a new variety of black cherry tomatoes grown in Vietnam (Solanum lycopersicum cv. OG). These results would help farmers to choose grafting/non-grafting techniques and suitable harvest maturity.

\section{Materials and methods}

\subsection{Experimental design}

Black cherry tomato (cv. OG) seeds were provided by the F1508 seed store (Ho Chi Minh City, Vietnam) and sown at Nam Long farm, Vinh Long province, Vietnam. After 23 days of sowing, 50 tomato plants were grafted with eggplant root (eggplant "EG 203" was obtained from the Asian Vegetable Development and Research Center). After 29 days of sowing, the remaining 50 tomato plants (without grafting) were transferred to pots for growing. After 13 days of grafting,
50 grafted tomato trees were also transferred to pots for growing. Sowing and growing process were all done at Nam Long farm (Vinh Long province). Marking the time when the flower started to form a fruit. At different stages (from 26-34 days and 24-32 days after fruit formation for non-grafted tomatoes and grafted tomatoes, respectively), fruits were harvested. Black tomatoes were put in perforated PVC and cardboard boxes and transported to the Food Technology laboratory of Can Tho University within $1 \mathrm{hr}$. Replications of three were made. The photos of fruit were taken and the physicochemical characteristics were determined.

\subsection{Physical properties}

\subsubsection{Fruit weight and size parameters}

The fruit weight was determined by an analytical balance with the accuracy of $0.0001 \mathrm{~g}$ (PR-series, Ohaus, USA). The fruit size was determined by two dimensions, namely height $(H)$ and diameter $(D)$, were measured by using digital calipers with an accuracy of $0.01 \mathrm{~mm}$ (MC 01120028, Gaogen, China). The geometric mean diameter $\left(D_{g}\right)$ was calculated by equation 1 (Yildiz et al., 2015)

$$
D_{g}(\mathrm{~mm})=\left(H D^{2}\right)^{1 / 3}
$$

The surface area $\left(S_{a}\right)$ and aspect ratio $\left(R_{a}\right)$ of the fruit were calculated by using equations 2 and 3 , respectively (Y1ldiz et al., 2015).

$$
\begin{aligned}
& S_{a}\left(\mathrm{~cm}^{2}\right)=\pi D_{g}^{2} \\
& R_{a}=D / H
\end{aligned}
$$

The sphericity $\left(S_{p}\right)$ defined as the ratio of the surface area of a sphere having the same volume as that of fruit to the surface area of the fruit was determined using equation 4 (Y1ldiz et al., 2015).

$S_{p}(\%)=100 \times\left(D_{g} / H\right)$

\subsubsection{Respiration rate}

Tomatoes $(200 \mathrm{~g})$ were put into a $20 \times 30 \mathrm{~cm}$ PE zip bag. The oxygen concentration was measured continuously. Respiration rate $(R)$ was determined by equation 5. Where $P$ is the permeability coefficient $\left(\mathrm{mL} . \mathrm{cm} . \mathrm{cm}^{-2} \cdot \mathrm{h}^{-1}\right), A$ is the surface area of the package $\left(\mathrm{cm}^{2}\right), L$ is the thickness of PE bag $(\mathrm{cm}), M$ is the weight of the sample $(\mathrm{kg}) ; y_{\mathrm{O} 2}$ is the oxygen concentration $(\% \mathrm{v} /$ v) (o: outside, i: inside).

$$
R\left(\mathrm{mLO}_{2} / \mathrm{kg}, \mathrm{h}\right)=\frac{P_{O_{2}} \times A}{100 \times L \times M} \times\left(y_{O_{2}}^{\circ}-y_{O_{2}}^{i}\right)
$$

\subsubsection{Firmness}

Fruit firmness was determined with a RheoTex (SD 700, Sun Science, Japan). Using a $1 \mathrm{~cm}$ - diameter cylindrical probe with a flat end in this case. The force required to press vertically into the middle of fruits for a $4 \mathrm{~mm}$ distance was measured and expressed in $\mathrm{g} / \mathrm{cm}^{2}$. 


\subsection{Chemical properties}

\subsubsection{Total soluble solids (TSS) content and $p H$} value

The whole tomatoes were ground in a blender (MXGM1011, Panasonic, Japan) for $1 \mathrm{~min}$ and the obtained puree was determined TSS content and $\mathrm{pH}$ value. The content of TSS was measured by a refractometer $(0-32 \%$, Atago, Japan) at $20^{\circ} \mathrm{C}$. The $\mathrm{pH}$ value was measured with a pH meter (Edge HI2020-01, Hanna, Vietnam) at $20^{\circ} \mathrm{C}$.

\subsubsection{Moisture content}

The moisture content $(W)$ was determined by drying the sample at $105^{\circ} \mathrm{C}$ to a constant weight and calculated using equation 6 . Where $m_{o}$ is the weight of the original sample, $m$ is the weight of the sample after drying.

$W(\%)=\frac{m_{0}-m}{m_{0}} \times 100$

\subsubsection{Total sugar content}

The total sugar content was determined by the colorimetric method with DNS reagent (Luong, 2003). Tomato puree $(3 \mathrm{~g})$ was weighed into a $100 \mathrm{~mL}$ flask with $50 \mathrm{~mL}$ of distilled water and $5 \mathrm{~mL}$ of $36.5 \% \mathrm{HCl}$ solution. The hydrolysis process was carried out at $60^{\circ} \mathrm{C}$ for 15 mins. The mixture was neutralized by the $30 \%$ $\mathrm{NaOH}$ solution to $\mathrm{pH} 7$ then filled up to a volume of 100 $\mathrm{mL}$ with distilled water and filtered through a filter paper. The filtrate $(2 \mathrm{~mL})$ was added $1 \mathrm{~mL}$ DNS reagent and placed in boiling water for 5 mins. The absorbance of the mixture was read at $540 \mathrm{~nm}$ using Spectrophotometer UV-VIS (722N, Inesa, China). The total sugar content $(S)$ was determined using equation 7 . Where $A$ is the reducing sugar content derived from the standard curve $(\mathrm{mg} / \mathrm{mL}), n$ is the dilution factor, $V$ is the volumetric flask volume $(100 \mathrm{~mL}), m$ is the weight of the sample (g).

$S(\%)=\frac{A \times n \times V \times 100}{m \times 1000}$

\subsubsection{Total acid content}

The total acid content was determined by the titration method (Yildiz et al., 2015). Tomato puree (10 g) was shaken with neutral water for $1 \mathrm{hr}$. The mixture was filled to a volume of $50 \mathrm{~mL}$ with neutral water and allowed to settle. The supernatant $(25 \mathrm{~mL})$ was added 5 drops of phenolphthalein and titrated with the $0.1 \mathrm{~N}$ $\mathrm{NaOH}$ solution until the mixture had a stable light pink. The total acid content was calculated by equation 8 . Where $n$ is the volume of the $0.1 \mathrm{~N} \mathrm{NaOH}$ solution used to titrate (mL), $K$ is the coefficient of citric acid (0.0064), $P$ is the weight of the sample $(\mathrm{g})$.

$A(\%)=n \times K \times \frac{50}{25} \times \frac{100}{P}$

\subsubsection{Anthocyanin content}

The anthocyanin content was determined by the $\mathrm{pH}$ differential method (Lee et al., 2005) with some modifications. Tomato puree $(5 \mathrm{~g})$ was filled to a volume of $50 \mathrm{~mL}$ with ethanol/water (1/1) solvent containing $1 \%$ $\mathrm{HCl}$ and extracted for 60 mins. The mixture was then separated by a centrifuge at $7000 \times g$ for 10 mins. The supernatant was diluted with two buffers of $\mathrm{pH} 1.0$ and 4.5 and read the absorbance at both 520 and $700 \mathrm{~nm}$ versus a blank of distilled water. The anthocyanin content was calculated as cyanidin-3-glucoside equivalent (equation 9). Where $A$ is $\left(\mathrm{A}_{520 \mathrm{~nm}}-\mathrm{A}_{700 \mathrm{~nm}}\right) \mathrm{pH}$ 1.0 - $\left(\mathrm{A}_{520 \mathrm{~nm}}-\mathrm{A}_{700 \mathrm{~nm}}\right) \mathrm{pH} 4.5, M$ is $449.2 \mathrm{~g} / \mathrm{mol}$ for cyanidin-3-glucoside, $k$ is the dilution factor, $l$ is the pathlength $(\mathrm{cm}), \varepsilon$ is 26900 - molar extinction coefficient for cyanidin-3-glucoside $\left(\mathrm{L} \times \mathrm{mol}^{-1} \times \mathrm{cm}^{-1}\right), V$ is the volume of extract $(\mathrm{mL}), m$ is the weight of the sample (g).

Anthocyanin (mg CE $/ 100 \mathrm{~g})=\frac{A \times M \times k \times V}{m \times \varepsilon \times l} \times 100 \times 1000$

\subsubsection{Lycopene content}

The lycopene content was determined by the low volume hexane extraction method (Fish et al., 2002; Davis et al., 2003). Tomato puree ( $0.6 \mathrm{~g})$ was mixed with $5 \mathrm{~mL}$ of acetone containing $0.05 \%$ butylated hydroxytoluene, $5 \mathrm{~mL}$ of $95 \%$ ethanol, $10 \mathrm{~mL}$ of hexane in a vial and extracted for 15 mins on a shaker at a speed of $180 \mathrm{rpm}$. The mixture was then added $3 \mathrm{~mL}$ of deionized water and shaken for 5 mins. The vial was left for 5 mins. The absorbance of the supernatant was read at $503 \mathrm{~nm}$ against a blank of hexane. The lycopene content was determined using equation 10 . Where $A_{503}$ is the absorbance of the extract at $503 \mathrm{~nm}, m$ is the weight of the sample ( $\mathrm{g})$.

$$
\begin{gathered}
\text { Lycopene }(\mu \mathrm{g} / \mathrm{g})=\frac{A_{508} \times 31.2}{m} \\
\text { 2.3.7 Vitamin C content }
\end{gathered}
$$

The vitamin $\mathrm{C}$ content was determined by the titration method (Lam et al., 2004). Tomato puree (10 g) was filled to a volume of $100 \mathrm{~mL}$ with $5 \% \mathrm{HCl}$ solution and filtered through a filter paper. The filtrate $(10 \mathrm{~mL})$ was added 5 drops of the $1 \%$ starch solution and titrated with the $0.001 \mathrm{~N} \mathrm{KIO}_{3} / \mathrm{KI}$ solution until the blue-black color appears. For the control, the sample extract was replaced by the $1 \% \mathrm{HCl}$ solution. The vitamin $\mathrm{C}$ content was calculated using equation 11 . Where $a$ and $b$ is the volume of $0.001 \mathrm{~N} \mathrm{KIO}_{3} / \mathrm{KI}$ solution used for titration the extract and the control, respectively $(\mathrm{mL}), 100$ is the volume of extract $(\mathrm{mL}), 0.088$ is the weight of ascorbic acid corresponds to $1 \mathrm{~mL}$ of $0.001 \mathrm{~N} \mathrm{KIO}_{3} / \mathrm{KI}$ solution $(\mathrm{mg}), m$ is the weight of the sample ( $\mathrm{g})$.

Vitamin $C(\mathrm{mg} / 100 \mathrm{~g})=\frac{(a-b) \times 0.088 \times 100}{10} \times \frac{100}{m}$ 


\subsubsection{Total phenolic content}

The total phenolic content was determined using Folin-Ciocalteu reagent (Teixeira et al., 2013) with some modifications. Tomato puree $(5 \mathrm{~g})$ was filled to a volume of $50 \mathrm{~mL}$ with $95 \%$ ethanol and extracted for 60 mins. The mixture was then separated by a centrifuge at 7000 $\times g$ for 10 mins. The supernatant $(0.2 \mathrm{~mL})$ was added 1.0 $\mathrm{mL}$ of $10 \%$ Folin-Ciocalteu reagent, left for 5 mins and then added $1.2 \mathrm{~mL}$ of $5 \% \mathrm{Na}_{2} \mathrm{CO}_{3}$ solution. After $2 \mathrm{hrs}$, the absorbance was recorded at $750 \mathrm{~nm}$. The total phenolic content was calculated as gallic acid equivalent (equation 12). Where $C$ is the content of gallic acid derived from the standard curve $(\mathrm{mg} / \mathrm{mL}), V$ is the volume of extract $(\mathrm{mL}), m$ is the weight of the sample $(\mathrm{g}), k$ is the dilution factor.

Phenolic (mg GAE $/ 100 \mathrm{~g})=\frac{\mathrm{C} \times \mathrm{V}}{\mathrm{m}} \times \mathrm{k} \times 100$

\subsubsection{Antioxidant activity}

Antioxidant activity was determined using the DPPH assay (Teixeira et al., 2013) with some modifications. Tomato puree $(5 \mathrm{~g})$ was filled to a volume of $50 \mathrm{~mL}$ with $95 \%$ ethanol and extracted for 60 mins. The mixture was then separated by a centrifuge at 7000 $\times g$ for 10 mins. The supernatant $(0.1 \mathrm{~mL})$ was added 2 $\mathrm{mL}$ of DPPH solution ( $0.21 \mathrm{mM}$ in $95 \%$ ethanol). For the control, the sample extract was replaced with $95 \%$ ethanol. The mixture was kept for $1 \mathrm{hr}$ before absorbance reading at $517 \mathrm{~nm}$. The percentage of DPPH free radical scavenging was calculated by equation 13 . Where $A_{\text {control }}$ is the absorbance of the control, $A_{\text {sample }}$ is the absorbance of the sample.

$$
\operatorname{DPPH}(\%)=\frac{A_{\text {control }}-A_{\text {sample }}}{A_{\text {control }}} \times 100
$$

\subsection{Data analysis}

Data analyses were carried out using the Statgraphics Centurion XV (U.S.A.). The significance/nonsignificance of results was determined using the OneWay ANOVA and Duncan test at the $95 \%$ confidence level $(\mathrm{P}=0.05)$.

\section{Results and discussion}

\subsection{The physical properties of black cherry tomatoes}

The color chart of the black cherry tomato "OG" variety at different maturity stages presented in Figure 1. Along with the color change was the change in physical properties and content of nutrients of the fruit. The tomato color gradually converted from green to greenorange to orange-red to deep red during maturation as a consequence of the synthesis of lycopene and depletion of chlorophyll (Arias et al., 2000). However, this change in the fruit skin was not obvious as in the fruit flesh due to the presence of anthocyanin.

The respiration rate of non-grafted tomatoes was still low on the $28^{\text {th }}$ day after fruit formation $\left(1.54 \mathrm{mLO}_{2} /\right.$ kg.h). This value increased gradually and reached its highest on the $32^{\text {nd }}$ day $\left(1.84 \mathrm{mLO}_{2} / \mathrm{kg} . \mathrm{h}\right)$ and then decreased slightly on the $34^{\text {th }}$ day (Figure 2a). Similarly, the respiration rate of grafted fruits decreased from the $24^{\text {th }}$ day $\left(1.73 \mathrm{mLO}_{2} / \mathrm{kg} . \mathrm{h}\right)$ to the $26^{\text {th }}$ day $\left(1.54 \mathrm{mLO}_{2} /\right.$ kg.h), then increased to the $30^{\text {th }}$ day $\left(1.92 \mathrm{mLO}_{2} / \mathrm{kg} . \mathrm{h}\right)$ and decreased again on the $32^{\text {nd }}$ day $\left(1.72 \mathrm{mLO}_{2} / \mathrm{kg} . \mathrm{h}\right)$ (Figure 2b). It was shown that the non-grafted tomatoes reached the maturity after 28 days of fruit formation and the $32^{\text {nd }}$ day was the full ripening time. For grafted tomatoes, the maturity and full ripening age were on the $26^{\text {th }}$ and $30^{\text {th }}$ day, indicating that the maturity of grafted fruits was faster. Tomato is classified as a climacteric ripening pattern, which means that they have a significant rise in respiration and ethylene production rates at the onset of the ripening process (Toivonen, 2007).

The weight and size of fruit are also important quality parameters that necessary for designing the postharvest system including sorting, handling, packaging, storage, and processing. These parameters of black cherry tomatoes were determined at the time of full maturity when fruits reached the maximum size (on the $28^{\text {th }}$ day for non-grafted tomatoes and on the $26^{\text {th }}$ day for grafted tomatoes). It was observed that the non-grafted and grafted tomatoes had the same weight and size (Table 1). Furthermore, the shape indexes of them, such as the sphericity (from $96.73 \%$ to $97.28 \%$ ) and the aspect ratio (from 0.95 to 0.96 ) indicated that the black cherry

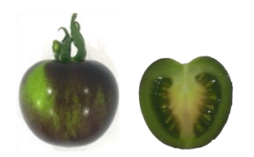

26 days

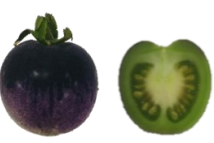

24 days

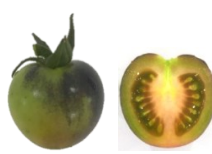

28 days

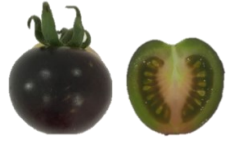

26 days

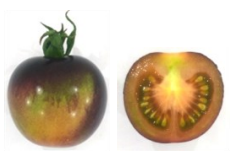

30 days

(a)

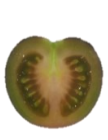

28 days

(b)

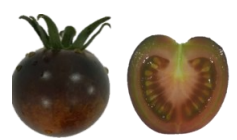

32 days

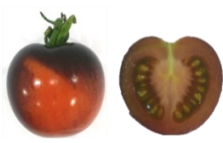

30 days

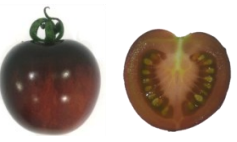

34 days

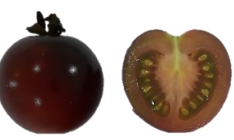

32 days

Figure 1. The color chart of (a) non-grated tomatoes and (b) grafted tomatoes at different harvest stages 

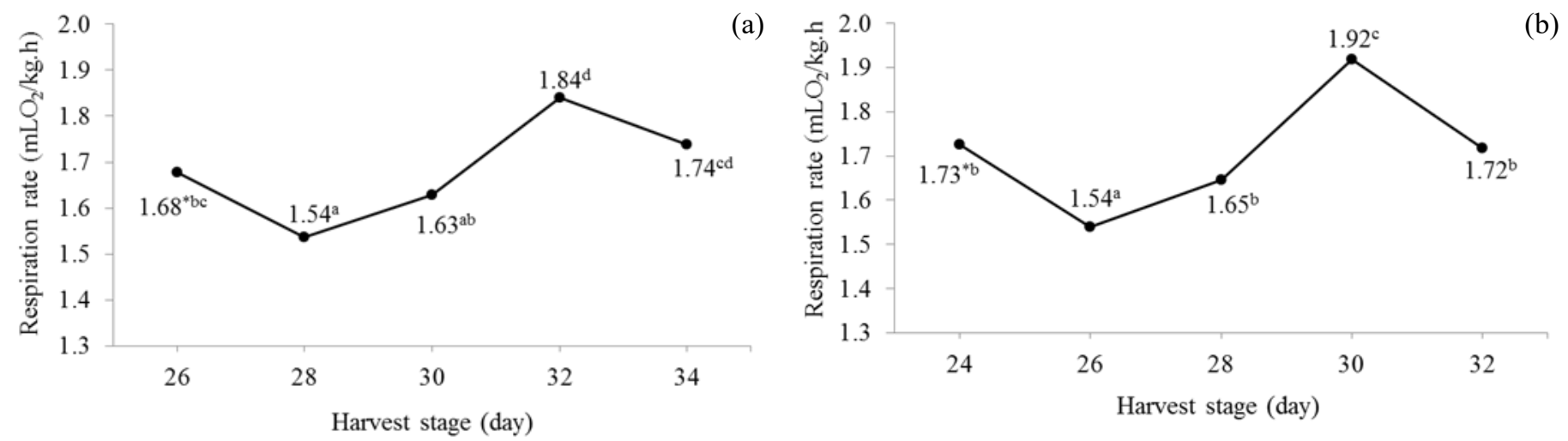

Figure 2. The respiration rate of (a) non-grated tomatoes and (b) grafted tomatoes at different harvest stages. Values are expressed as the mean of three replicates. Values with different superscript are significantly different at $5 \%$ significance level $(\mathrm{P}<0.05)$.
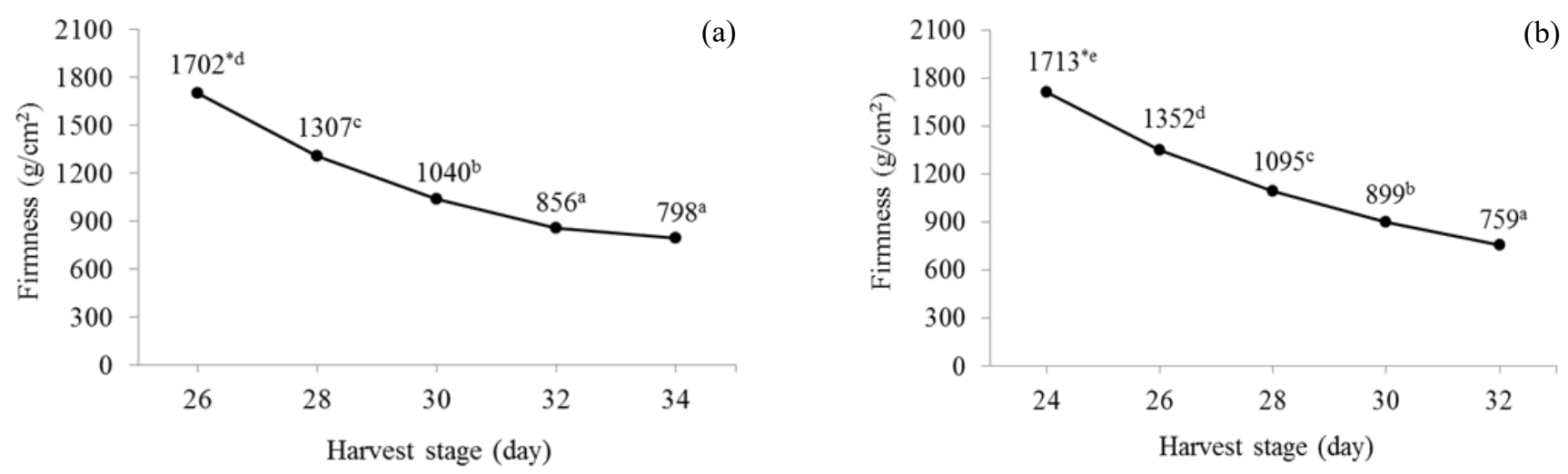

Figure 3. The firmness of (a) non-grated tomatoes and (b) grafted tomatoes at different harvest stages. Values are expressed as the mean of three replicates. Values with different superscript are significantly different at $5 \%$ significance level $(\mathrm{P}<0.05)$.

tomato fruit could be considered as an equivalent sphere.

The firmness decreased rapidly at the early harvest stage and then more slowly at the later harvest stage in both non-grafted and grafted tomatoes but there was no significant difference in firmness between two types of fruits (Figure 3). The texture and firmness of fruits and vegetables are based on the presence and interactions of different chemical components, like pectins in the middle lamellae and the cellulose/hemicellulose matrix in the primary cell wall, and on physical aspects like arch structure and turgor. The turgor and part of pectin are susceptible to enzymatic degradation during ripening, thereby contributing to the variable part of the firmness (Van Dijk et al., 2006).

Table 1. Fruit weight and size of non-grafted tomatoes on the $28^{\text {th }}$ day and grafted tomatoes on the $26^{\text {th }}$ day

\begin{tabular}{lcc}
\hline \multicolumn{1}{c}{ Fruit weight and size } & $\begin{array}{c}\text { Non-grafted } \\
\text { tomatoes }\end{array}$ & $\begin{array}{c}\text { Grafted } \\
\text { tomatoes }\end{array}$ \\
\hline Weight $(\mathrm{g})$ & $21.99 \pm 1.61$ & $22.25 \pm 1.28$ \\
Height $(\mathrm{mm})$ & $25.98 \pm 1.75$ & $26.40 \pm 1.36$ \\
Diameter $(\mathrm{mm})$ & $24.87 \pm 2.14$ & $25.11 \pm 1.83$ \\
Geometric mean diameter $(\mathrm{mm})$ & $25.21 \pm 1.84$ & $25.52 \pm 1.64$ \\
Sphericity $(\%)$ & $97.28 \pm 2.70$ & $96.73 \pm 1.37$ \\
Surface area $\left(\mathrm{cm}^{2}\right)$ & $20.03 \pm 2.90$ & $20.51 \pm 2.64$ \\
Aspect ratio & $0.96 \pm 0.11$ & $0.95 \pm 0.08$ \\
\hline
\end{tabular}

Values are expressed as mean \pm standard deviation.

\subsection{The chemical properties of black cherry tomatoes}

The moisture content varied from 92.73 to $94.86 \%$ and 92.45 to $94.23 \%$ for non-grafted and grafted fruits, respectively with higher values in the first harvest stage, followed by reductions in the content throughout the ripening cycle (Figure 4). During the ripening of the fruit, chemical compounds are synthesized reaching maximum content at the end of ripening, therefore the content of moisture decreases gradually (Schulz et al., 2015).

As could be seen in Table 2, the content of total sugar and TSS of non-grafted tomatoes increased by harvest stage and peaked on the $32^{\text {nd }}$ day, after that, it tended to decrease on the day of $34^{\text {th }}$. When the harvest stage was extended from 26 to 32 days, the increase in total sugar content was due to the conversion of starch during fruit ripening (Prasad et al., 2018), however, after the fruit was fully ripening, the hydrolysis process no longer took place and the sugar participated in the respiration leading to a decrease in total sugar (Bashir and Abu-Goukh, 2003). Similarly, the total sugar and TSS content of grafted fruits increased from the $24^{\text {th }}$ harvest day and reached the highest value on the $30^{\text {th }}$ day, then decreased on the $32^{\text {nd }}$ day (Table 3). These results were also consistent with the obtained results of Mini (2017) for the "PKM-1" tomato variety. 

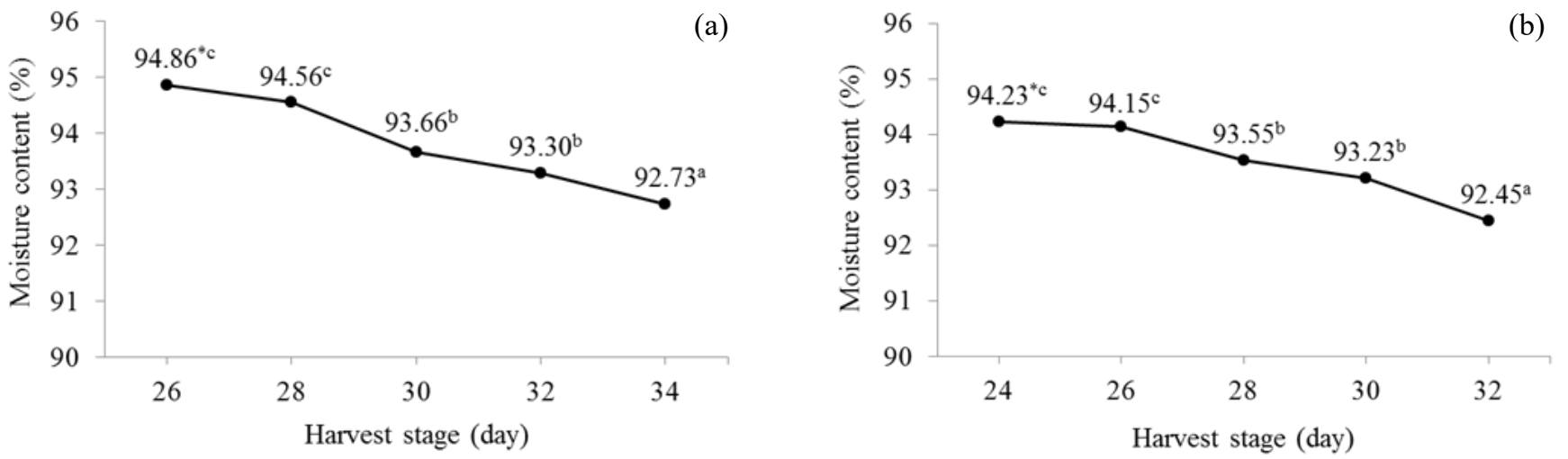

Figure 4. The moisture content of (a) non-grated tomatoes and (b) grafted tomatoes at different harvest stages. Values are expressed as the mean of three replicates. Values with different superscript are significantly different at $5 \%$ significance level $(\mathrm{P}<0.05)$.

Table 2. The total sugar and TSS content of non-grafted tomatoes at different harvest stages

\begin{tabular}{ccc}
\hline Harvest stage (day) & Total sugar content (\%) & TSS content $(\%)$ \\
\hline 26 & $2.92^{\mathrm{a}}$ & $3.83^{\mathrm{a}}$ \\
28 & $3.39^{\mathrm{b}}$ & $4.50^{\mathrm{b}}$ \\
30 & $4.41^{\mathrm{c}}$ & $5.53^{\mathrm{c}}$ \\
32 & $4.89^{\mathrm{d}}$ & $6.17^{\mathrm{e}}$ \\
34 & $4.57^{\mathrm{cd}}$ & $5.83^{\mathrm{d}}$ \\
\hline
\end{tabular}

Values are expressed as the mean of three replicates. Values with different superscript within the column are significantly different at $5 \%$ significance level $(\mathrm{P}<0.05)$.

The total acid content and $\mathrm{pH}$ changed in two opposite directions (Tables 4 and 5). The total acid content increased with the harvest stage until the fruit was fully ripening and reached its highest values, $0.578 \%$ and $0.506 \%$, for non-grafted and grafted tomatoes on the $32^{\text {nd }}$ and the $30^{\text {th }}$ day, respectively. This component tended to decrease later. The predominant acid in tomatoes is malic acid and is utilized as a substrate for respiration and esterification, creating a special aroma for fruits, which is the reason for the decreasing trend in acidity in the later stage (Mini, 2017). Conversely, the $\mathrm{pH}$ value reached the lowest on the $32^{\text {nd }}$ day (4.21) and the $30^{\text {th }}$ day (4.35) for nongrafted and grafted tomatoes corresponding to the time of the highest total acid content.

The bioactive compounds such as anthocyanin, lycopene, vitamin $\mathrm{C}$, and other phenolics were all valuable components in black cherry tomatoes, which

Table 4. The total acid content and $\mathrm{pH}$ value of non-grafted tomatoes at different harvest stages

\begin{tabular}{ccc}
\hline Harvest stage (day) & Total acid content $(\%)$ & $\mathrm{pH}$ \\
\hline 26 & $0.288^{\mathrm{a}}$ & $4.94^{\mathrm{d}}$ \\
28 & $0.447^{\mathrm{b}}$ & $4.66^{\mathrm{c}}$ \\
30 & $0.501^{\mathrm{c}}$ & $4.43^{\mathrm{b}}$ \\
32 & $0.578^{\mathrm{d}}$ & $4.21^{\mathrm{a}}$ \\
34 & $0.514^{\mathrm{c}}$ & $4.40^{\mathrm{b}}$ \\
\hline
\end{tabular}

Values are expressed as the mean of three replicates. Values with different superscript within the column are significantly different at $5 \%$ significance level $(\mathrm{P}<0.05)$.
Table 3. The total sugar and TSS content of grafted tomatoes at different harvest stages

\begin{tabular}{ccc}
\hline Harvest stage (day) & Total sugar content (\%) & TSS content $(\%)$ \\
\hline 24 & $3.46^{\mathrm{a}}$ & $4.57^{\mathrm{a}}$ \\
26 & $4.53^{\mathrm{b}}$ & $5.77^{\mathrm{b}}$ \\
28 & $4.94^{\mathrm{c}}$ & $6.20^{\mathrm{c}}$ \\
30 & $4.27^{\mathrm{d}}$ & $6.47^{\mathrm{d}}$ \\
32 & $5.11^{\mathrm{cd}}$ & $6.17^{\mathrm{c}}$ \\
\hline
\end{tabular}

Values are expressed as the mean of three replicates. Values with different superscript within the column are significantly different at $5 \%$ significance level $(\mathrm{P}<0.05)$.

determine the antioxidant activity of fruits. During ripening, these components changed in different directions (Tables 6 and 7).

It was worth noting that the non-grafted black tomatoes reached the highest anthocyanin content on the $34^{\text {th }}$ day of harvest stage $(4.32 \mathrm{mg} \mathrm{CE} / 100 \mathrm{~g})$ but there was no statistically significant difference between the two days of $30^{\text {th }}$ and $32^{\text {nd }}$. The anthocyanin accumulation process takes place in three stages: the first phase with a rapid increase in the concentration, a transitional phase characterized by a decreasing accumulation rate until a maximum concentration, and a final phase of decreasing concentration (Schulz et al., 2015). At the first stage of harvest, the content of lycopene was very low $(8.74 \mu \mathrm{g} /$ g) which increased almost 5 times during ripening and reached $42.28 \mu \mathrm{g} / \mathrm{g}$ on the $34^{\text {th }}$ day. Increased level of lycopene in tomatoes with the harvest stage is due to the ripening advancement of fruits and conversion of

Table 5. The total acid content and $\mathrm{pH}$ value of grafted tomatoes at different harvest stages

\begin{tabular}{ccc}
\hline Harvest stage (day) & Total acid content (\%) & $\mathrm{pH}$ \\
\hline 24 & $0.354^{\mathrm{a}}$ & $4.80^{\mathrm{d}}$ \\
26 & $0.437^{\mathrm{b}}$ & $4.68^{\mathrm{c}}$ \\
28 & $0.484^{\mathrm{c}}$ & $4.47^{\mathrm{b}}$ \\
30 & $0.506^{\mathrm{c}}$ & $4.35^{\mathrm{a}}$ \\
32 & $0.487^{\mathrm{c}}$ & $4.43^{\mathrm{ab}}$ \\
\hline
\end{tabular}

Values are expressed as the mean of three replicates. Values with different superscript within the column are significantly different at $5 \%$ significance level $(\mathrm{P}<0.05)$. 
Table 6. The content of bioactive compounds and DPPH free radical scavenging activity of non-grafted tomatoes at different harvest stages

\begin{tabular}{cccccc}
\hline $\begin{array}{c}\text { Harvest stage } \\
(\text { day })\end{array}$ & $\begin{array}{c}\text { Anthocyanin } \\
(\mathrm{mg} \mathrm{CE} / 100 \mathrm{~g})\end{array}$ & $\begin{array}{c}\text { Lycopene } \\
(\mu \mathrm{g} / \mathrm{g})\end{array}$ & $\begin{array}{c}\text { Vitamin C } \\
(\mathrm{mg} / 100 \mathrm{~g})\end{array}$ & $\begin{array}{c}\text { Phenolic } \\
(\mathrm{mg} \mathrm{GAE} / 100 \mathrm{~g})\end{array}$ & $\begin{array}{c}\text { DPPH } \\
(\%)\end{array}$ \\
\hline 26 & $3.42^{\mathrm{a}}$ & $8.74^{\mathrm{a}}$ & $30.18^{\mathrm{a}}$ & $48.74^{\mathrm{d}}$ & $57.21^{\mathrm{a}}$ \\
28 & $3.82^{\mathrm{b}}$ & $17.70^{\mathrm{b}}$ & $34.98^{\mathrm{a}}$ & $42.73^{\mathrm{c}}$ & $60.50^{\mathrm{b}}$ \\
30 & $4.27^{\mathrm{c}}$ & $24.60^{\mathrm{c}}$ & $42.74^{\mathrm{b}}$ & $40.61^{\mathrm{b}}$ & $68.56^{\mathrm{c}}$ \\
32 & $4.31^{\mathrm{c}}$ & $38.79^{\mathrm{d}}$ & $55.69^{\mathrm{d}}$ & $38.69^{\mathrm{a}}$ & $76.58^{\mathrm{d}}$ \\
34 & $4.32^{\mathrm{c}}$ & $42.28^{\mathrm{e}}$ & $49.47^{\mathrm{c}}$ & $37.99^{\mathrm{a}}$ & $76.33^{\mathrm{d}}$ \\
\hline
\end{tabular}

Values are expressed as the mean of three replicates. Values with different superscript within the column are significantly different at 5\% significance level $(\mathrm{P}<0.05)$.

Table 7. The content of bioactive compounds and DPPH free radical scavenging activity of grafted tomatoes at different harvest stages

\begin{tabular}{cccccc}
\hline $\begin{array}{c}\text { Harvest stage } \\
(\text { day })\end{array}$ & $\begin{array}{c}\text { Anthocyanin } \\
(\mathrm{mg} \mathrm{CE} / 100 \mathrm{~g})\end{array}$ & $\begin{array}{c}\text { Lycopene } \\
(\mu \mathrm{g} / \mathrm{g})\end{array}$ & $\begin{array}{c}\text { Vitamin C } \\
(\mathrm{mg} / 100 \mathrm{~g})\end{array}$ & $\begin{array}{c}\text { Phenolic } \\
(\mathrm{mg} \mathrm{GAE} / 100 \mathrm{~g})\end{array}$ & $\begin{array}{c}\text { DPPH } \\
(\%)\end{array}$ \\
\hline 24 & $3.88^{\mathrm{a}}$ & $17.14^{\mathrm{a}}$ & $32.12^{\mathrm{a}}$ & $47.29^{\mathrm{c}}$ & $65.61^{\mathrm{a}}$ \\
26 & $4.21^{\mathrm{b}}$ & $22.54^{\mathrm{b}}$ & $36.78^{\mathrm{a}}$ & $41.73^{\mathrm{b}}$ & $66.82^{\mathrm{b}}$ \\
28 & $4.39^{\mathrm{c}}$ & $32.62^{\mathrm{c}}$ & $47.35^{\mathrm{b}}$ & $39.37^{\mathrm{a}}$ & $73.50^{\mathrm{c}}$ \\
30 & $4.45^{\mathrm{c}}$ & $41.12^{\mathrm{d}}$ & $63.53^{\mathrm{c}}$ & $39.15^{\mathrm{a}}$ & $81.63^{\mathrm{e}}$ \\
32 & $4.42^{\mathrm{c}}$ & $44.49^{\mathrm{e}}$ & $51.61^{\mathrm{b}}$ & $38.67^{\mathrm{a}}$ & $79.84^{\mathrm{d}}$ \\
\hline
\end{tabular}

Values are expressed as the mean of three replicates. Values with different superscript within the column are significantly different at $5 \%$ significance level $(\mathrm{P}<0.05)$.

chloroplasts to chromoplasts (Mini, 2017). The vitamin $\mathrm{C}$ content also increased from $30.18 \mathrm{mg} / 100 \mathrm{~g}$ on the $26^{\text {th }}$ day to $55.69 \mathrm{mg} / 100 \mathrm{~g}$ on the $32^{\text {nd }}$ day, and then decreased to $49.47 \mathrm{mg} / 100 \mathrm{~g}$ on the $34^{\text {th }}$ day. In tomato fruits, ascorbic acid content increases with maturity and stage of ripening, however, once fruit reaches the fully ripe stage, ascorbic acid content starts to decline (Mini, 2017). A decrease in total phenolic content with ripening was observed. This content decreased sharply from the $26^{\text {th }}$ day (48.74 mg GAE/100 g) to the $32^{\text {nd }}$ day (38.69 $\mathrm{mg}$ GAE/100 g). The phenolic content on two harvest days of $32^{\text {th }}$ and $34^{\text {th }}$ was not different significantly. Phenolic acts as an antibody of a plant, in the early stages of development, many antibodies are needed to resist nature. After adapting to the environment, plants do not synthesize phenolic compounds. Meanwhile, during ripening, phenolic can be oxidized by polyphenol oxidase (Ayaz et al., 2008). The antioxidant activity of non-grafted tomatoes expressed by the DPPH free radical scavenging activity reached the highest level on the $32^{\text {nd }}$ harvesting day $(76.59 \%)$, after which there was a decreasing trend on the harvest day of $34^{\text {th }}$ but they were not different significantly. The phenolic compounds were a major contributor to the antioxidant activity of plants (Song et al., 2010), so a decrease in phenolic content would affect the antioxidant activity of black cherry tomatoes. However, the antioxidant activity of tomatoes is derived from a mixture of antioxidant compounds, including carotenoids, ascorbic acid, and total phenolic (Bhandari et al., 2016). It was observed that the changing trend of bioactive compounds in grafted tomatoes was also similar. However, the anthocyanin content was found highest on the $30^{\text {th }}$ day
(4.45 mg CE/100 g) but not significantly different compared to the $28^{\text {th }}$ and $32^{\text {nd }}$ days.

\section{Conclusion}

The appropriate harvest stage of black cherry tomatoes (cv. OG) was on the $30^{\text {th }}$ day for non-grafted fruits and on the $28^{\text {th }}$ day for grafted fruits, at this time, the anthocyanin content was maximum while the other bioactive compounds remained low. If collected at the fully ripening stage, the fruits would be vulnerable in transport and storage. Tomato is a climacteric fruit, so that, it will ripen and the remaining compounds may continue changing under storage conditions. Anthocyanin is synthesized on plants during growing under the sunlight, this component does not increase after harvesting. The grafting helped the plant to grow faster as shown by an earlier harvesting stage and the harvested fruits had a higher level of bioactive compounds such as anthocyanin, lycopene, and vitamin $\mathrm{C}$ than the non-grafted fruits. It is necessary to further investigate the impact of grafting on the resistance to bacterial wilt of the black cherry tomato plants to better understand the importance of this technique.

\section{Conflict of interest}

The authors declare no conflict of interest.

\section{References}

Alda, L.M., Gogoasa, I., Bordean, D.M., Gergen, I., Alda, S., Moldovan, C. and Nita, L. (2009). Lycopene content of tomatoes and tomato 
products. Journal of Agroalimentary Processes and Technologies, 15(4), 540-542.

Arias, R., Lee, T.C., Logendra, L. and Janes, H. (2000). Correlation of lycopene measured by HPLC with the $\mathrm{L}^{*}, \mathrm{a}^{*}, \mathrm{~b}^{*}$ color readings of a hydroponic tomato and the relationship of maturity with color and lycopene content. Journal of Agricultural and Food Chemistry, 48(5), 1697-1702. https:// doi.org/10.1021/jf990974e

Ayaz, F.A., Demir, O., Torun, H., Kolcuoglu, Y. and Colak, A. (2008). Characterization of polyphenoloxidase (PPO) and total phenolic contents in medlar (Mespilus germanica L.) fruit during ripening and over ripening. Food Chemistry, 106(1), 291-298.

j.foodchem.2007.05.096

Bashir, H.A. and Abu-Goukh, A.B.A. (2003). Compositional changes during guava fruit ripening. Food Chemistry, 80(4), 557-563. https:// doi.org/10.1016/S0308-8146(02)00345-X

Besri, M. (2001). New developments of alternatives to methyl bromide for the control of tomato soilborne pathogens in covered cultivation in a developing country, Morocco. Retrieved from website: https:// crec.ifas.ufl.edu/extension/soilipm/2001\%20MBAO/ Besri,\%20Mohamed/Besri,\%20Mohamed\%20(9)\% 202001\%20Presentation.pdf

Bhandari, S.R., Cho, M.C. and Lee, J.G. (2016). Genotypic variation in carotenoid, ascorbic acid, total phenolic, and flavonoid contents, and antioxidant activity in selected tomato breeding lines. Horticulture, Environment, and Biotechnology, 57(5), 440-452. https:// doi.org/10.1007/s13580-016-0144-3

Black, L.L., Wu, D.L., Wang, J.F., Kalb, T., Abbass, D. and Chen, J.H. (2003). Grafting tomatoes for production in the hot-wet season. Asian Vegetable Research and Development Center, 3, 551.

Bletsos, F.A. (2005). Use of grafting and calcium cyanamide as alternatives to methyl bromide soil fumigation and their effects on growth, yield, quality and fusarium wilt control in melon. Journal of Phytopathology, 153(3), 155-161. https:// doi.org/10.1111/j.1439-0434.2005.00945.x

Cuartero, J., Bolarin, M.C., Asins, M.J. and Moreno, V. (2006). Increasing salt tolerance in the tomato. Journal of Experimental Botany, 57(5), 1045 -1058. https://doi.org/10.1093/jxb/erj102

Davis, A.R., Fish, W.W. and Perkins-Veazie, P. (2003). A rapid spectrophotometric method for analyzing lycopene content in tomato and tomato products. Postharvest Biology and Technology, 28
(3), 425-430. https://doi.org/10.1016/S0925-5214 (02)00203-X

Fish, W.W., Perkins-Veazie, P. and Collins, J.K. (2002). A quantitative assay for lycopene that utilizes reduced volumes of organic solvents. Journal of Food Composition and Analysis, 15(3), 309-317. https://doi.org/10.1006/jfca.2002.1069

Ford, N.A. and Erdman, J.W. (2012). Are lycopene metabolites metabolically active? Acta Biochimica Polonica, 59(1), 2159. https://doi.org/10.18388/ abp.2012_2159

Gonzali, S., Mazzucato, A. and Perata, P. (2009). Purple as a tomato: towards high anthocyanin tomatoes. Trends in Plant Science, 14(5), 237-241. https://doi.org/10.1016/j.tplants.2009.02.001

Helyes, L., Pék, Z. and Lugasi, A. (2006). Tomato fruit quality and content depend on stage of maturity. HortScience, 41(6), 1400-1401. https:// doi.org/10.21273/HORTSCI.41.6.1400

Ilahy, R., Hdider, C. and Tlili, I. (2009). Bioactive compounds and antioxidant activity of tomato high lycopene content advanced breeding lines. Tunisian Plant Science and Biotechnology I. The African Journal of Plant Science and Biotechnology, 3 (Special Issue 1), 1-6.

Kaur, H., Chauhan, S. and Sandhir, R. (2011). Protective effect of lycopene on oxidative stress and cognitive decline in rotenone induced model of Parkinson's disease. Neurochemical Research, 36(8), 1435-1443. https://doi.org/10.1007/s11064-011-0469-3

Lam, T.B., Nguyet, T.N.M. and Thu, D.T.N. (2004). Food Biochemistry Experiment. Vietnam: National University Ho Chi Minh City.

Lee, J., Durst, R.W. and Wrolstad, R.E. (2005). Determination of total monomeric anthocyanin pigment content of fruit juices, beverages, natural colorants, and wines by the $\mathrm{pH}$ differential method: collaborative study. Journal of $A O A C$ international, 88(5), 1269-1278. https:// doi.org/10.1093/jaoac/88.5.1269

Li, H., Deng, Z., Liu, R., Young, J.C., Zhu, H., Loewen, S. and Tsao, R. (2011). Characterization of phytochemicals and antioxidant activities of a purple tomato (Solanum lycopersicum L.). Journal of Agricultural and Food Chemistry, 59(21), 1180311811. https://doi.org/10.1021/jf202364v

Lila, M.A. (2004). Anthocyanins and human health: an in vitro investigative approach. BioMed Research International, 2004(5), 306-313. https:// doi.org/10.1155/S111072430440401X

Luong, N.D. (2003). Biotechnology Experiment. Vietnam: National University Ho Chi Minh City. 
Mes, P.J., Boches, P., Myers, J.R. and Durst, R. (2008). Characterization of tomatoes expressing anthocyanin in the fruit. Journal of the American Society for Horticultural Science, 133(2), 262-269. https:// doi.org/10.21273/JASHS.133.2.262

Min, J.Y. and Min, K.B. (2014). Serum lycopene, lutein and zeaxanthin, and the risk of Alzheimer's disease mortality in older adults. Dementia and Geriatric Cognitive Disorders, 37(3-4), 246-256. https:// doi.org/10.1159/000356486

Mini, M.L. (2017). Influence of harvesting stage and storage temperature on nutritional quality of tomato (Lycopersicon esculentum Mill) cv. PKM-1. International Journal of Biochemistry Research and Review, 16(4), 1-8. https://doi.org/10.9734/ IJBCRR/2017/31858

Moneruzzaman, K.M., Hossain, A.B.M.S., Sani, W. and Saifuddin, M. (2008). Effect of stages of maturity and ripening conditions on the biochemical characteristics of tomato. American Journal of Biochemistry and Biotechnology, 4(4), 336-344. https://doi.org/10.3844/ajbbsp.2008.336.344

Mordente, A., Guantario, B., Meucci, E., Silvestrini, A., Lombardi, G.E., Martorana, E., Giardina, B. and Bohm, V. (2011). Lycopene and cardiovascular diseases: an update. Current Medicinal Chemistry, 18(8), 1146-1163. https:// doi.org/10.2174/092986711795029717

Prasad, K., Jacob, S. and Siddiqui, M.W. (2018). Fruit maturity, harvesting, and quality standards. In Siddiqui, M.W. (Ed.) Preharvest Modulation of Postharvest Fruit and Vegetable Quality, p. 41-69. USA: Academic Press. https://doi.org/10.1016/B978 -0-12-809807-3.00002-0

Rivard, C.L. and Louws, F.J. (2008). Grafting to manage soilborne diseases in heirloom tomato production. HortScience, 43(7), 2104-2111. https:// doi.org/10.21273/HORTSCI.43.7.2104

Schulz, M., Borges, G.D.S.C., Gonzaga, L.V., Seraglio, S.K.T., Olivo, I.S., Azevedo, M.S., Nehring P., Santod de Gois J., Silva de Almeida T., Vitali, L., Spudeit, D.A., Micke, G.A., Borges, D.L.G. and Fett, R. (2015). Chemical composition, bioactive compounds and antioxidant capacity of juçara fruit (Euterpe edulis Martius) during ripening. Food Research International, 77(Part 2), 125-131. https:// doi.org/10.1016/j.foodres.2015.08.006

Song, F.L., Gan, R.Y., Zhang, Y., Xiao, Q., Kuang, L. and Li, H.B. (2010). Total phenolic contents and antioxidant capacities of selected Chinese medicinal plants. International Journal of Molecular Sciences, 11(6), 2362-2372. https://doi.org/10.3390/ ijms11062362
Teixeira, B., Marques, A., Ramos, C., Serrano, C., Matos, O., Neng, N.R., Nogueira, J.M.J., Saraiva, J.A. and Nunes, M.L. (2013). Chemical composition and bioactivity of different oregano (Origanum vulgare) extracts and essential oil. Journal of the Science of Food and Agriculture, 93(11), 2707-2714. https://doi.org/10.1002/jsfa.6089

Toivonen, P.M. (2007). Fruit maturation and ripening and their relationship to quality. Stewart Postharvest Review, 3, 1-5. https://doi.org/10.2212/spr.2007.2.7

Van Dijk, C., Boeriu, C., Peter, F., Stolle-Smits, T. and Tijskens, L.M.M. (2006). The firmness of stored tomatoes (cv. Tradiro). 1. Kinetic and near infrared models to describe firmness and moisture loss. Journal of Food Engineering, 77(3), 575-584. https://doi.org/10.1016/j.jfoodeng.2005.07.029

Viskelis, P., Jankauskiene, J. and Bobinaite, R. (2008). Content of carotenoids and physical properties of tomatoes harvested at different ripening stages. Foodbalt, 2008, 166-170.

Yetisir, H. and Sari, N. (2003). Effect of different rootstock on plant growth, yield and quality of watermelon. Australian Journal of Experimental Agriculture, 43(10), 1269-1274. https:// doi.org/10.1071/EA02095

Yıldız, G., İzli, N., Ünal, H. and Uylaşer, V. (2015). Physical and chemical characteristics of goldenberry fruit (Physalis peruviana L.). Journal of Food Science and Technology, 52(4), 2320-2327. https:// doi.org/10.1007/s13197-014-1280-3

Zhang, W., Xie, F., Lan, X., Gong, S. and Wang, Z. (2018). Characteristics of pectin from black cherry tomato waste modified by dynamic high-pressure microfluidization. Journal of Food Engineering, 216, 90-97. https://doi.org/10.1016/ j.jfoodeng.2017.07.032 